\title{
The Effectiveness of Extracurricular (Qur'an Hadith) in State High School (SMAN) 15 Takengon Binaan Nenggeri Antara
}

\author{
Hermawati \\ Universitas Islam Negeri (UIN) Sunan Kalijaga Yogyakarta, Indonesia \\ hermawati4550@gmail.com
}

\begin{abstract}
Al-Qur'an and Hadith have an essential role, especially in high school-age children, where very few of them learn and understand the contents of the Qur'an and Hadith. In addition, students do not yet understand the importance of understanding the Qur'an and Hadith for the future. Many of them lack interest, lack parental roles, and an unsupportive environment. This study aims to increase knowledge and understanding related to the Effectiveness of the Additional Lesson Activity (Qur'an) Hadith in the afternoon at SMAN 15 Takengon guided by Tereng Antara. Local policies began to erode with the inclusion of modern culture. For example, many Takengon students spend time playing games in internet cafes. They do not have time to practice the Koran and the Koran as room decoration, even making antiques that are only displayed in a glass cabinet, never read moreover study it. Reflecting on this, there is great hope for educators to apply the teachings of Al-Qur'an Hadith to all students.
\end{abstract}

Al-Qur'an dan Hadits memiliki peran penting khususnya pada anak-anak usia sekolah menengah atas, dimana sangat sedikit dari mereka untuk mempelajari dan memahami isi kandungan Al-Qur'an dan hadist. Selain itu, peserta didik belum paham akan pentingnya memahami Al-Qur'an dan hadist untuk masa depan. banyak diantara mereka yang kurang memiliki minat, kurangnya peran orang tua, serta lingkungan yang tidak mendukung . Penelitian ini bertujuan untuk meningkatkan pengetahuan..dan pemahaman terkait Efektivitas Kegiatan Pelajaran Tambahan (Qur'an Hadits) Sore Hari Di SMAN 15 Takengon Binaan Nenggeri Antara. Kebijakan lokal mulai terkikis dengan masuknya budaya modern. Sebagai contoh, banyak peserta didik Takengon yang menghabiskan waktu main game di warnet sehingga tidak mempunyai waktu untuk mengamalkan Al-Quran dan Al-Qur'an dijadikan hiasan ruangan saja, bahkan jadikan barang antik yang hanya dipajang di dalam lemari kaca, tidak pernah dibaca apalagi mempelajarinya. Bercermin pada hal itu, besar harapan pada pendidik agar menerapkan ajaran Al-qur'an Hadist pada seluruh peserta didik.

Keywords: Effectiveness, Extracurricular, Qur'an Learning Hadith.

Received: February 23, 2021; Revised: May 21, 2021; Accepted: June 23, 2021 


\section{INTRODUCTION}

Education is to cultivate personality and a sense of responsibility that can control mental, moral and physical training that can produce high-cultured humans, so education is meaningful. Islamic education means giving a person's ability to lead his life by the ideals and values of Islam that have imbued and coloured his personality patterns obtained from an appropriate education system. It can be understood that Islamic religious education is a guideline for the life of a servant of Allah that must be followed, an accurate reference for survival in this world and the hereafter. The purpose of Islamic education must be oriented to the nature of education. Namely, humans are created to have goals and tasks in life, not by chance.

Education is inseparable from the expression of quality. The success of quality education can be seen from the perspective of education itself (education perspective). Quality education can be formed through collaboration between educators and students in learning. The teacher is the number one person in learning activities who have an important influence and role in providing learning materials to students, such as directing, guiding, achieving learning goals, and students' scientific and skills to get a better life. Educators hold the authority to find and implement appropriate methods to make the subject matter easier to understand

Teaching time is part of the primary factor of learning effectiveness. The curriculum and professionalism of a teacher are indispensable in effective learning and produce good quality. In addition to this, time is an integral part of implementing education for the success or failure of an educational process. In addition, the influence of time can also determine students' interest and attention to learning activities.

The activities of the learning implementation process require adequate time. Because time conditions can also affect the quality of student learning and the right time, learning effectiveness can be obtained by optimizing learning materials, making syllabus, activity plans, methods, and appropriate infrastructure to achieve goals. Practical learning activities involve a policy that the government has decided on in an educational curriculum. And school educational institutions can adopt a school policy called school autonomy.

In the context of the Indonesian world of education, there are several Islamic educational institutions, such as madrasah educational institutions, whose existence is under the auspices of the Ministry of Religion. Madrasah is the name of the meaning of darasa, which has the sense of a place to seek knowledge. The terms madrasah and school have the same purpose, that is, the same place of study. However, according to Karel A, Steenbrink, the terms madrasah and school are distinguished because they have different characteristics.

In his time, madrasas were places to teach and study Islam, science and other skills. Al-Qur'an and Hadith lessons are found in Islamic Religious Education (PAI) (Zukhrufin, Anwar and Sidiq, 2021). It can be said that everyone knows the term PAI. Islamic Religious Education is teaching that cultivates human nature to gain understanding, appreciation, and practice. So it is clear that PAI education to maintain, develop knowledge of religion and practice it by the rules of religion is suitable to achieve quality human life. And as for the benefits of studying the Qur'an and Hadith itself, namely as a guide and reference for human beings in running the wheel of life, whether related to worldly rules or the hereafter. 
Imitating the Qur'an and Hadith is an obligation for every Muslim, and every parent is required to guide and direct their children to study the Qur'an and Hadith as a provision and head for their social life in the community. Given that the child is the trust of God Almighty, who is the responsibility of parents, and both parents must provide education, full attention to each child's development. One of the things that must be instilled in the child as early as possible is the value of faith and morals to the child, and this can be taught based on the understanding given from the verses of the Qur'an and Hadith so that it affects his life (Ikhwan, 2018).

Ironically, practising the Qur'an and Hadith in today's society, exceptionally high school students, is very minimal to want to read, study, and understand its contents. It is as if the Qur'an is only used as a room decoration, even used as an antique that is only displayed in a glass cupboard, never read or studied. Whereas if we know the virtues of reading and practising the Qur'an and Hadith in our daily lives, we can run the wheel of a life well through the instructions, get peace of mind, be on the right path, by the content in the Qur'an. And Allah always provides help for those who always love, read, study, and practice the Qur'an (Ikhwan, Anwar and Mahmudah, 2021).

The current reality we often encounter amid society, many school children cannot read the Qur'an fluently and correctly. Several factors cause this to happen, including the lack of interest for students to learn the Qur'an, the lack of parental roles in motivating children in additional learning activities of the Qur'an, and an unsupportive environment, because there are already many places students play, such as playing games in the internet cafe. Thus, educational institutions, especially Islamic education, are needed to help children get a better education from professional educators who can convey various knowledge in the field of religion. Al-Qur'an Hadith is one of the subjects of Islamic education in Madrasas in general. The lessons of everyday life are closely related to the Al-Qur'an Hadith.

\section{METHOD}

This type of research is field research, using a naturalistic qualitative approach (Sugiono, 2013). This research was conducted for approximately four months, from August to August. December 2019. The research site is SMAN 15 Takengon, fostered by Nenggeri Antara. The location was chosen with three considerations. First, the only school that implements character education is Takengon. Second, one of the most popular schools in Takengon. Third, there are learning activities of the Qur'an hadith as an extracurricular activity that is applied. These subjects are PAI teachers and students of SMAN 15 Takengon. Determination of research subjects is done naturally. This means that it develops as it is, not manipulated by researchers. The object of the research is the effectiveness of additional learning activities of the Qur'an hadith in the afternoon at SMAN 15 Takengon Binaan Nengri Antara. The research procedure was carried out in four steps: 1) observation, 2) interviews, 3) documentation, 4) data reduction, data display, and 5) drawing conclusions or verification (Arikunto, 2013). The data collection tool or research instrument is the researcher himself. The researchers went into the field themselves to conduct direct observations and in-depth interviews about the effectiveness of additional learning of the Qur'an hadith, starting from the initial formulation of activities, preparation of research achievements, fields of study and curriculum structure. Data were obtained through participatory 
observation, researchers conducted systematic observations and recordings of learning activities and matters related to research, and interviews were conducted independently and controlled (Sugiono, 2017).

Documents associated with this research are in the form of documentation of artefacts, manuscripts related to the development of learning the Qur'an and hadith. The inductive model is used in data analysis. The data that has been collected is then analyzed by taking four components of interactive analysis, namely data collection, data reduction, data display, and drawing conclusions/verification. (Sugiono, 2014). Each piece interacts and forms a cycle. The data obtained is then checked for correctness to ensure the validity of the data. The level of trustworthiness of the research results is achieved by fulfilling the criteria for credibility or internal validity, transferability or external validity, dependability or reliability and confirmability or objectivity (Soejono, 1999).

\section{RESULT AND DISCUSSION}

\section{The process of additional teaching and learning activities (Al-Qur'an Hadith)}

The research was carried out at SMAN 15 Takengon Binaan Nenggeri Antara, namely, to determine the effectiveness of additional learning of the Qur'an Hadith. To obtain the data above, the authors conducted interviews with respondents on Tuesday, August 13 2019, interviews and direct observations during class hours on August 28 and October 2. Regarding the data on the effectiveness of additional learning of the Qur'an Hadith obtained, it can be seen the results of interviews with the teacher of other subjects of the Qur'an Hadith, namely Zulkipli:

"Additional lessons of the Qur'an and Hadith are carried out once a week, and it starts from half-past three until Asr time" (Budi, 2019).

And then, the author describes the results of interviews at SMAN 15 Takengon Binaan Nenggeri as follows:

When delivering lessons, the method used by the teacher varies, depending on the material being given. Before starting the additional study of Al-Qur'an Hadith in the afternoon, the teacher asks questions about the previous material because the teacher wants to repeat the last material taught to remember the material that has been conveyed. Sometimes, when presenting a verse according to the demands of whether the poem is memorized, the teacher will use the Drill method to repeat together, making it easier for children to remember the verse-verse given (Daradjat, 1995). Then there is also after the verse has been learned, the following week the interpretation will be conveyed, of course with various methods, such as ijmali interpretation, and sometimes looking at the context of the verse as well, if the poem is interpreted maudhui, the teacher also uses stories. The stories in the Qur'an convey in-depth to students (Majid, 2013). The goal is to make it easier for students to understand the material, stories such as prophets, angels, people's stories, etc.

During the delivery of the method delivered by the teacher, students at SMAN 15 Takengon can absorb the lessons well when the teacher has presented the Qur'an Hadith material in various ways. So the results or scores obtained by students when each test is carried out show the value that the children understand the Qur'an Hadith, 
especially the verses and hadiths that have been discussed because when students are tested, they are just measured. As stated by students.

"We are delighted to learn Al-Qur'an Hadith, and the learning process is enjoyable". (Maulana students, Takengon Assisted High School)

Then in the learning process, students are very disciplined. For example, if there are late students for class, it must explain precisely why the student is late. The delay of students during class hours does not become a habit. Being late in the context is understood, such as vehicle disturbances and weather disturbances, but if being late becomes a habit, it doesn't. And in general, if it is taken from the percentage of attendance, it is possible that the meeting is estimated to be only two or three people who are not present or a maximum of five, and even then with information that can be received. Some were due to illness, some were absent because there was a family activity, and everyone absent had previously asked permission from the picket teacher.

In the learning process, some students are late to enter, the teacher sees the delay of the students. However, from 2010 the teacher taught the Al-Qur'an Hadith. The students who were late could be said to be absent. It's about two or five minutes late at most. So if they are only five minutes late, the teacher is still in the preamble, still in the opening stage in the learning process. So, no students have entered the new lesson for half an hour and the new students come. Why can it happen like that? This is because of school rules that have made children not dare to go late. Almost all teachers never repeat lessons for late students because students are only a matter of minutes late, and new teachers want to enter the opening stage and even then the early opening stage. So the teacher never repeats it if only because students are late.

Still, in the learning process, the way teachers condition students who are quite a lot in one room, many teachers are constrained in dealing with their students. Usually, the teacher only deals with twenty-eight or thirty students in one room. However, in the additional learning activities of the Qur'an Hadith, the teacher deals with one hundred and twelve students at a time. Why is it like that, because a strict rule already binds students at this school? If the teacher has entered, the student has the right to be silent.

Then so that students focus on following the learning process, students are given material fun. For example, the material presented is replayed using infocus. This is also expressed by the Qur'an Hadith teacher who states that:

"My way of dealing with students learning is by making the room comfortable so that students who are in the room when taking lessons feel at home and comfortable while attending lessons. With me, I create a learning atmosphere so that there is no noise for students. Moreover, plus I use the media when studying, namely infocus. Students feel at home when I deliver the material along with videos related to the material. And you can also make a PowerPoint" (Idawati, 2019).

And the following way, the teacher monitors the students so that not a single student escapes the teacher's supervision, so that students do not dare to talk to their friends who can reduce the concentration of learning.

But, whether the number of students is small or large, it lies in the ability of local mastery of a teacher (Tohirin, 2008). Local knowledge can be in the form of face-toface with students and the movement of the teacher's room in the classroom. For example, a teacher at the time of teaching sits in the front and does not want to walk 
around in delivering the subject matter, and it can make the children sitting in the back not be noticed. So these are the ways that teachers have applied to master the class by always maintaining eye contact with students. At SMAN 15 Takengon Binan Nenggeri Antara, this teacher is like how he handles his type with children. Even with this way of teaching, it almost makes the children not dare to speak while studying. Because students feel monitored always. The teacher continues to instil in the students that no matter how many, there are one hundred and twelve. The teacher tells them that they are always under the teacher's supervision, even though they are themselves. And it is proven, it can be confirmed during the learning process. This was also expressed by Yulida, who stated that:

"There is not a single student who dares to make a fuss while studying because the teacher who teaches usually punishes the noisy students with unexpected punishments. For example, when one of the students ignores the teacher while looking, the student is asked to repeat what the teacher said, or it could be the punishment for memorizing a verse or hadith that was just taught. (Yulidayanti, 2019).

Related to the learning process, namely during the question and answer session. The question and answer process is open to the public without being appointed. After the teacher has presented the Qur'an Hadith material, the teacher provides opportunities for students to discuss and ask what they don't understand. The teacher never limits the number of students who want to ask questions as long as the question is still related to the material being taught.

Of course, after following a lesson, there are several tasks that the teacher must give to students. So at the end of each class, the teacher usually gives the charge depending on the material presented. For example, suppose some students have problems memorizing verses or reading verses during the verse presentation process, then at the end of the lesson. In that case, the teacher will ask students to discuss or analyze recitation of tajwid laws that are difficult to read. But if it is not too difficult, then the teacher no longer asks students to discuss it.

Meanwhile, related to the evaluation of learning, the teacher uses an additional learning evaluation of the Qur'an Hadith by the provisions of education. Non-formal and formal assessment, both written and unwritten. So the review for taking normative report cards, of course, following school rules when the exam is held, the Qur'an Hadith is also tested. But if there is an unwritten test in memorization to evaluate the children's ability to memorize verses, the teacher will remember it. Usually, so three or two poems or one hadith one poem are presented, the teacher will ask for a memorization deposit. Like the first week of the material, the second week of the material, the third week is just memorizing. It's for evaluating the ability to remember. After learning later, the children were asked to submit a summary or outline of the verses or hadiths they had memorized. That's the only way to evaluate it. For normative evaluation, it is in the form of a written test. So basically, there is a written evaluation, and there is also an unwritten evaluation. 


\section{Additional learning outcomes (Al-Qur'an Hadith) at SMAN 15 Takengon}

Table 1. Other Learning Outcomes of Al-Qur'an Hadith Class X:

\begin{tabular}{llc}
\hline No. & Name & Score \\
\hline 1. & Aina Masri & 83 \\
\hline 2. & Rina Simehate & 90 \\
\hline 3. & Selvia Katiara & 89 \\
\hline 4. & Maulana Heru Mulya & 89 \\
\hline 5. & Anisa Hizri Linge & 89 \\
\hline
\end{tabular}

Table 2. Additional Learning Results of Al-Qur'an Hadith Class XI:

\begin{tabular}{llc}
\hline No. & Name & Score \\
\hline 1. & Sri Wijayanti & 99 \\
\hline 2. & Triana Ulfa & 99 \\
\hline 3. & Erna Mahyana & 96 \\
\hline 4. & Puna Mauliza & 87 \\
\hline 5. & Nuri Asma Febrianda & 96 \\
\hline
\end{tabular}

Table 3. Additional Learning Outcomes of AI-Qur'an Hadith Class XII:

\begin{tabular}{llc}
\hline No. & Name & Score \\
\hline 1. & MH. Nuke Bahgie & 93 \\
\hline 2. & Yulidayanti & 93 \\
\hline 3. & Vera Sandopa & 94 \\
\hline 4. & Fajri Indallah & 93 \\
\hline 5. & Kartika Wulandari & 93 \\
\hline
\end{tabular}

As stated by Zulkipli regarding additional learning outcomes of the Al-Qur'an Hadith students who say that:

"It turns out that there is a very significant effect of the additional learning that we teach in the afternoon" (Budi, 2019).

The author concludes the results of the interview that the additional lessons of the Qur'an Hadith are beneficial for students in learning and understanding religious lessons in general. And then, the author describes the results of the interview with $\mathrm{Mr}$ Zulkipli as a teacher in the field of Islamic studies at SMAN 15 Takengon Binaan Nenggeri as follows:

After completing the additional learning process of Al-Qur'an Hadith, of course, there will be a developmental impact on students, first, the changes from 2010 to 2017 ago. The first visible change was the completion of the PAI UASBN questions. It turns out that there is a very significant effect of additional learning taught in the afternoon. Because the verses or hadiths that are ordered to be memorized are sourced from their religious books. In general, when the UASBN exam took place, 12th graders had memorized verses and hadiths from class 10, 11, and class 12 material. So that their National Standard School Final Examination (UASBN) scores were from 2010 to 2017, if for the district of SMAN 15 Takengon, this could be changed. Keep it up. Still always in the first rank, that's one of the effects. Second, the second impact is that when the teacher has explained the interpretation of the verse, it appears in the children's daily attitude. For example, in children's everyday attitudes, the teacher explains avoiding arrogant behaviour (Majid, 2013). It appears that the children interacting with each other are not complacent, and it is also possible that there is a 
factor inherited by their classmates who have preceded them. Indirect guidance from seniors who have graduated from the same education bench. This is a real impact so that the vision and mission of the school to create students with character can indeed be felt at SMAN 15 Takengon Binaan Nenggeri Antara. This was also expressed by Erna, who stated that:

"After we took lessons from the Qur'an Hadith, we felt a lot of changes in attitude, such as being better people obeying the rules and being able to memorize more verses and hadiths" (Mahyana, 2019).

From the results of observations and interviews, the teacher gives lessons to students according to the material that already exists in the learning curriculum because the curriculum is a tool used for education (Hamalik, 2006). In every material presented, the teacher requires to understand and understand what is being conveyed. Suppose there are still students who do not understand. In that case, the teacher will give assignments to students to write or comment on how much students' understanding and understanding of the material has been conveyed. Teachers adapt learning methods to the circumstances of students based on their needs, using various modes of knowing. This is considered an effective way for additional learning of the Qur'an Hadith. The media that the teacher uses are in the form of package books, Al-Quran and infocus. The teacher will continue to repeat the material being taught, and try to make students understand the additional learning activities of the Al-Qur'an Hadith perfectly, and for students who do not understand the teacher continues to strive until the students understand. The response of students when learning activities take place is excellent and can be accepted by students. To overcome students who have difficulty understanding the material provided, the teacher takes a personal approach to students, guides them and provides motivation in the hope that these students can understand the lesson. The standard passing grade of the minimum passing criteria (KKM) for additional subjects of Al-Qur'an Hadith is 75. After looking at students' learning outcomes in the other issues of Al-Qur'an Hadith, which can be seen from the semester scores of students in learning, In addition to the Al-Qur'an Hadith, they get a pretty good score are above the average value.

The main goal in this additional semester of Al-Qur'an Hadith learning is knowledge of religious knowledge. Religious knowledge comes from the subject matter taught at school. From the lessons conveyed by the teacher to students, students respond to these lessons well and master and understand these lessons and practice them for their lives and society. So effective learning can be seen from the results of changes in a person's behaviour from bad to good, dance does not understand, and will know. And get high learning scores in additional learning activities of the Qur'an Hadith.

\section{The Effectiveness of Additional Learning Activities (Al-Qur'an Hadith) Afternoon at SMAN 15 Takengon Binaan Nenggeri Antara}

Effectiveness has consequences and effects and is efficient (Miarso dkk, 2004) (Departemen Pendidikan R.I., 1988). To achieve the goal of additional lessons, the hadith Qur'an that teachers and students want impacts what is done. The same is said in the practical Indonesian dictionary, impact effects, results. Effectively achieve the desired goal - effectiveness success (Supardi, 2013). Effectiveness is used to measure one of the quality standards of education by achieving learning objectives. To attain practical learning objectives, teachers at SMAN 15 Takengon combine learning materials to make them more exciting and quickly understood by students, and they 
are arranged as well as possible. Such as covering human, material, facilities, equipment, and procedures directed to change in a positive direction according to students' potential. Teachers can carry out effective learning by providing independent learning opportunities and providing broad freedom of activity for students to understand the concept of learning (Hamalik dkk, 2001). Vygotsky states that the social experience of students is essential in thinking development activities (Mulyasa, 2012). Because with direct knowledge, children can develop their minds with imagination according to what they see. Not only that, but effectiveness is also closely related to how the process is for the success of a goal or the results obtained, the level of the element's available power and user satisfaction (Fitra Ardiansyah 2016).

Effectiveness means the effort made to achieve the goals set by the critical needs, by the plan, both in the use of data, facilities, and time or trying through certain activities both physically and non-physically to obtain maximum results both quantitatively. As well as qualitative, effectiveness means striving to achieve the planned goals. There must be timeliness, data suitability, plan suitability, and facilities as needed, such as extracurricular learning activities.

Extracurricular is an additional activity in education outside of class hours whose purpose is to help students develop, according to the needs, potential, talents, and interests of students through special activities (Ardy, 2013). Extracurricular activities are activities carried out in developing specific aspects of the current curriculum, including how the actual application of the material learned by students is adapted to their needs and social environment. The application of learning outcomes obtained by students is by the demands of their life needs and the surrounding environment. To achieve extracurricular activities optimally, students must support activities optimally to achieve activity goals (Nor dkk, 2016). All extracurricular activities carried out in schools for students and educators are by the child's potential. Therefore they must support them maximally to achieve learning objectives kaffah because this activity can take place well without any obstacles. This opinion is by the Regulation of the Minister of Education and Culture of the Republic of Indonesia Number 62 of 2014 concerning Extracurricular Activities paragraph (2), namely: Extracurricular activities are organized to develop the potential, talents, interests, abilities, personality, cooperation, and independence of students optimally to support the achievement of national education goals.

The Effectiveness of Afternoon Additional Learning Activities (Qur'an Hadith) at SMAN 15 Takengon Binan Nenggeri Antara. in general able to add an understanding of Islam, especially in the field of Qur'an Hadith to students and students at SMAN 15 Takengon. And with the additional lessons of Islam (Qur'an Hadith) also make students able to memorize verses and hadiths of the Prophet, which are then applied in life. This is all because of the role of school institutions in providing additional religious lessons for children.

The students are, of course, taught first to know what the Al-Qur'an Hadith is so that the students know and have a stronger desire to learn the Al-Qur'an Hadith, what exactly is the function of the Qur'an Hadith. This makes it easier for educators to understand the material and knowledge of students who study it. As we know that the Qur'an and As-Sunnah a source of Islamic teachings that can guarantee people, when using them, will not go astray forever (Nata, 2012). The Qur'an-Hadith lesson at SMAN 15 Takengon Binaan Nenggeri Antara is one of the additional materials that is 
expected to be able to increase understanding of the Qur'an-Hadith that students have studied during the Intracurricular lesson, which is only 2 hours in the morning. And even then, not all of them discuss the material of the Qur'an-Hadith. Because at the high school level, this is different from the M.A., which specialises in the main lessons about the Al-Qur'an Hadith. The Qur'an Hadith Supplementary Study activities are carried out by providing material, studying, understanding, deepening the study of the Qur'an and Hadith, especially regarding verses and hadiths that will be estimated to be included in the PAI UASBN exam.

In general, al-Qur'an-Hadith subjects have a contribution in motivating students to learn to understand and practice the values contained in the Qur'an and Hadith as the primary source of Islamic teachings and at the same time serve as guidelines. Live in everyday life.

In this case, students of SMAN 15 Takengon fostered by Nenggeri Antara, especially in the field of religion, can expand the ability of students to strengthen faith and piety to Allah SWT, which is at least as necessary as having noble character and noble character. And these additional religious subjects (Qur'an Hadith) are included in the unit of Islamic religious education subjects where the objectives and functions of AlQur'an Hadith subjects are not far from Islamic religious education subjects. Al-Qur'an Hadith education in schools as a very urgent part of religious education is not the only determining factor in forming the character and personality of students. Still, AlQur'an Hadith subjects have a role in motivating students to practice religious values as contained in the Qur'an and Hadith in everyday life.

Al-Qur'an Hadith subjects are elements of Islamic religious education subjects in schools aimed at students to understand the Qur'an and Hadith as a source of Islamic teachings and practice their contents as a way of life and be able to read fluently, translate, conclude the contents of the content and understand and practise it in life as well.

\section{CONCLUSION}

The process of teaching and learning activities (Al Qur'an Hadith) in the afternoon at SMAN 15 Takengon from the beginning of the planning has been going well until now. It is still making an excellent contribution to students and schools in general as well as the teacher's efforts in delivering the material for the Afternoon Supplementary Lesson Activities (Qur'an Hadith) by providing lessons according to the material, using teaching media and using appropriate methods for learning the Qur'an Hadith By using creative ways so that learning can be fun and understood by students. The results of education (Al-Qur'an Hadith) in the afternoon at SMAN 15 Takengon can be seen from the number of students who can apply the effects of learning Al-Qur'an Hadith correctly and adequately, and it can be proven from the behaviour of students and from the value of learning Al-Qur'an Hadith students who show an excellent deal. Schools should equip learning support facilities with various teaching media so that learning can be carried out and run more effectively. Teachers should make learning plans that directly involve students and apply active knowledge so that students are more engaged in learning the Qur'an Hadith. 
87 Al-Hayat: Journal of Islamic Education (AJIE)

e-ISSN: 2599-3046 (online) | Volume 5, Issue 1 | January - June 2021

p-ISSN:2657-1781 (print)

\section{REFERENCES}

[1] Ardy, W. N. (2013) Menumbuhkan Pendidikan Karakter Di SD (Konsep, Praktek Dan Strategi). Jogjakarta: Ar-Ruzz Media.

[2] Arikunto, S. (2013) Prosedur Penelitian. Jakarta: Rineka Cipta.

[3] Budi, Z. (2019) Wawancara Dengan Bapak Selaku Guru Pendidikan Agama Islam SMAN 15 Takengon Binaan Nenggeri Antara.

[4] Daradjat, Z. (1995) Metodik Khusus Pengajaran Agama Islam. Jakarta: Bumi Aksara.

[5] Hamalik dkk (2001) Psikologi Belajar Dan Mengajar. Bandung: Sinar Baru Algensindo.

[6] Hamalik, O. (2006) Manajemen Pengembangan Kurikulum. Bandung: Remaja Rosdakarya.

[7] Idawati (2019) Wawancara Dengan Selaku Guru PAI SMAN 15 Takengon Binaan Nenggeri Antara.

[8] Ikhwan, A. (2018) Filsafat Pendidikan Islam: Memahami Prinsip Dasar. Yogyakarta: Diandra Kreatif.

[9] Ikhwan, A., Anwar, S. and Mahmudah, N. (2021) 'Tahsin and Tahfidz Learning System at Integrated Islamic Elementary School ( SDIT ) Insan Madani During the Pandemic Covid-19', Al-Hayat: Journal of Islamic Education (AJIE), 5(1), pp. 111.

[10] Mahyana, E. (2019) Wawancara Selaku Peserta Didik SMAN 15 Takengon Binaan Nenggeri Antara.

[11] Majid, A. (2013) Perencanaan Pembelajaran. Bandung: PT Remaja Rosdakarya.

[12] Miarso dkk (2004) Menyemaii Benih Teknologi Penddikan. Jakarta: Kencana.

[13] Mulyasa, E. (2012) Manajemen PAUD. Bandung: Remaja Rosdakarya.

[14] Nata, A. (2012) Ilmu Pendidikan Islam. Jakarta: Kencana Prenada Media Group.

[15]Nor dkk (2016) 'Pelaksanaan Kegiatan Ektrakurikuler Dalam Rangka Pengembangan Nilai-Nilai Karakter Peserta Didik Untuk Menjadi Warga Negara Yang Baik Di SMA Kopri Banjarmasin', Jurnal Pendidikan Kewarganegaraan, $6(11)$.

[16] Soejono, A. (1999) Metode Penelitian: Suatu Pemikiran dan Penerapannya. Jakarta: Rineka Cipta.

[17] Sugiono (2013) Sugiono, Metode Penelitian Kuantitatif Kualitatif Dan R\&D. Bandung: Alfabeta.

[18] Sugiono (2014) Metode Penelitian Pendidikan (Pendekatan Kuantitatif, Kualitatif, Dan $R \& D$. Bandung: Alfabeta.

[19] Sugiono (2017) Metode Penelitian Kuantitatif, Kualitatif, dan R\&D. 25th edn. Bandung: Alfabeta.

[20] Supardi (2013) Sekolah Efektif, Konsep Dasar Dan Praktiknya. Jakarta: Rajawali Pers. 
[21] Tohirin (2008) Psikologi Pembelajaran Pendidikan Agama Islam. Jakarta: PT RajaGrafindo Persada.

[22] Yulidayanti (2019) Wawancara Dengan Selaku Peserta Didik SMAN 15 Takengon Binaan Nenggeri Antara.

[23] Zukhrufin, F. K., Anwar, S. and Sidiq, U. (2021) 'Desain Pembelajaran Akhlak Melalui Mata Pelajaran Pendidikan Agama Islam', JIE: Journal of Islamic Edication, 6(2). 